\title{
IMPLEMENTATION OF FINANCIAL LITERACY EDUCATION ON ACCOUNTING EDUCATION STUDENTS THROUGH UNIVERSITY-BANK PARTNERSHIP TO REDUCE STUDENT'S CONSUMTIVE BEHAVIOR
}

\author{
Dhany Efita Sari \\ des576@ums.ac.id \\ Universitas Muhammadiyah Surakarta
}

\begin{abstract}
A country's financial sector is evaluated based on the level of public financial literacy, which is good if the percentage at least 30\%. However, the OJK survey in 2016 indicated the Indonesian financial literacy is low $(21.8 \%)$. People with the culture of financial literacy are expected to appropriately manage inflation issue, and family and personal budgets including financial assets and debt management, in order to improve their lives. Particularly for the younger generations, the financial literacy in daily implementation is crucial. In fact, most of them, especially students, indicated consumptive, glamorous attitudes and low saving habit. This study aimed to describe the implementation of financial literacy education on the students of Accounting Education, Universitas Muhammadiyah Surakarta through University-Bank Partnership Program. This research is a literature study using qualitative approach. It was done by examining and analyzing the prevailing problems based on the existing literature. Based on the analysis, it can be concluded that consumptive behavior can be reduced by providing financial literacy education in Higher Education. The program include: (1) provision of financial literacy education through financial literacy car, (2) simulation of banking products, (3) preparation of financial literacy content in the curriculum, (4) provision of technical assistance in facilitating educational institutions, (5) thematic community service program on financial literacy, and (6) provision of OJK outlets in universities. Essentially, this program is expected to reduce student's consumptive behavior and enhance financial literacy among the younger generations.
\end{abstract}

Keywords: education; financial literacy; bank; consumptive behavior; student. 


\section{INTRODUCTION}

Currently, Indonesia can be classified into one of developing countries in Southeast Asia with relatively low economic growth rate. It is apparently a consequence of various aspects, including the lack of understanding of people towards financial literacy. In 2016, the Financial Services Authority of Indonesia or known as Otoritas Jasa Keuangan (OJK) reported a survey result that indicated the poor financial literacy of people, which was merely $21.8 \%$. Meanwhile, to have a liable financial sector, the minimum level of financial literacy should be at least $30 \%$.

Dvarakova (2009) in Tomaskova, et al., (2011) explicated financial literacy as a set of knowledge, skills and attitudes of citizens necessary to financially secure themselves and their family in contemporary society. It deals with their active role in the market of financial products and services. In fact, society with a determined financial literacy is able to cope with money and price issues, and manage both family and personal budgets, including the management of financial assets and debt in order to change lives. The financial literacy is a particular part of a wider economic literacy. The economic literacy comprises the competence to secure income, decide the consequences of personal decisions on the current and future income, determine the orientation on the labor market, to make decisions about expenditures, and so on.

Chen and Volpe (2002) suggested that financial literacy shows the financial understanding about the general knowledge of financial savings and insurance investments. Lusardi and Mitchell (2014) also suggested people with a high understanding of financial literacy relatively have a better economic life hence they also make financial decisions easily.

Based on the definitions, it can be declared that financial literacy as the intelligence in managing personal financial assets is one of the intelligences that must be possessed by today's modern society. Proper financial management is a strategy done to gain maximum benefit from the money. In general, an individual will make three financial decisions regarding with personal life, namely: 1) how much to spend in each period; 2) is there any excess income and how to invest it; and 3) how to afford the consumption and investment.

As an effort to attain the financial well-being, an individual should comprehend the knowledge, attitudes, and implementation of healthy personal finances. The extent to which the knowledge, attitude and implementation of a person in managing finances is called financial literacy. Meanwhile, Lusardi (2010) estimated that as the next generation, students in Higher Education will face the increasing complexity in financial products, services, and markets, in addition to have more financial risks in the future than the older generation (Lusardi, 2010).

The significance of education to improve understanding of financial literacy among the students, particularly in Higher Education, has encouraged the banking sector to conduct educational programs of banking solutions and financial literacy through various activities and publication about banking products through mass media. The programs are carried out both independently or collaboratively with OJK as the government's agency. They are almost similar to those commenced by Bank Central Asia (BCA) in 2016 through its official website (https://www.bca.co.id/), which is aimed at increasing the financial 
literacy of the society, especially for the young generation. The programs formulated by BCA include: 1) Financial literacy education with SiMOLEK. The activity is done in a van called SiMOLEK, which stands from Mobil Literasi Keuangan, and instigated by OJK; 2) Financial literacy education for students, through Simpel/Simpel IB or Student Savings product. Education and activation of this product is conducted in several locations, such as in Bandung and Kuningan, West Java as well as Grobogan, Central Java; and 3) Financial literacy education and saving simulation to 200 students in SD Pringgabaya East Lombok and SD Gondanglegi Malang, East Java; 300 students in SMP Negeri 6 Kota Serang, SMP Negeri 1 Gadingrejo, SMP Negeri 1 Semanu, SMP Negeri 1 Ponjong and SMP Negeri 1 Karangmojo.

Financial literacy education program is also conducted by OJK in cooperation with Persyarikatan Muhammadiyah. In fact, OJK continually improves several Islamic financial programs, financial literacy and consumer protection in the financial services sector. In addition, OJK has initiated partnership with several institutions, including Persyarikatan Muhammadiyah and Universitas Muhammadiyah Malang. The scope of the Memorandums of Understanding between OJK and Muhammadiyah ranges from joint research to the assistance in the development of Islamic finance in the financial service sector activities. In addition, collaboration in the provision of education for employees or citizens to improve understanding of the activities of Islamic-based financial services products is also initiated. Financial literacy skill is developed through verbal and written socialization, preparation of an educational curriculum design that involves description of activities in the financial services sector, and provision of technical assistance in facilitating educational institutions. Furthermore, several programs are also set up, namely the Thematic Community Service Program (Kuliah Kerja Nyata Tematik) on financial literacy and consumer protection and the Financial Services Authority (OJK) outlet in UMM campus.

Briefly, financial literacy is essential to enhance the public understanding in managing their finance appropriately, particularly on adolescents and Higher education students. Those who are in the social group of glamorous peers will have competitive feeling and desire to go beyond others. A teenager whose friends have high-tech gadgets or smartphones will compete to have a more sophisticated smartphone than friends. It encourages consumptive behavior among adolescents, especially students.

Wardhani (2009) defined consumptive as extravagant or redundant behavior in consuming goods or services. Sebayang, Yusuf, and Priyatama (2011) identified consumptive behavior is an action performed by individual, including to purchase or consume goods or services-which are not a priority of their needs-excessively and without rational consideration, and done only for physical satisfaction and temporary desire. From the explanation, it can be elucidated that consumptive behavior is the action of a person in consuming goods and/or services merely to gratify desire instead of to fulfill priority needs.

Students of Accounting Education, Universitas Muhammadiyah Surakarta (UMS) can be categorized into adolescent group who have a propensity to pursue glamorous lifestyle as well as being conspicuous, stylish, consumptive and financially irresponsible. At the same time, they obtain education about financial literacy in the class, yet it is perceived to be insufficient to improve their understanding about the matter. Hence, 
collaboration or partnership program is conducted by the Accounting Education Study Program with the bank in order to reduce the consumer behavior of students.

Based on the background, the formulation of the problem in this study is how the implementation of financial literacy education by initiating partnership with bank in order to reduce the student consumptive behavior? Furthermore, this study aimed at describing the implementation of financial literacy education in Accounting Education UMS by initiating partnership with bank in order to reduce the student consumptive behavior.

\section{METHODOLOGY}

This study is a literature study with qualitative approach. The literature study was conducted by examining and analyzing possible causes with respect to consumptive behavior that occurs among students. Furthermore, the solution to solve the existing problems is based on the formulated existing literature review.

Solutions obtained from various literature reviews are combined into innovative systems or models that are useful in solving the issues. In-depth analysis is supported by findings reported by previous studies. Creswell (2009) suggested the capacity of literature review in accomplishing many objectives, in which it shares the results of relevant studies to the readers. It depicts the significance of relevant significance in supporting the meaning and the research to obtain a comprehensive analysis.

In this research, there are five stages to obtain conclusion and solution in overcoming the student consumptive behavior. They consist of: first, the inventory of ideas and notions conducted by reading scientific articles relating to consumptive behavior. Second, the collection of relevant references in the form of books and scientific articles relating to the selected topic. Third, the inventory of relevant theories and approaches to support selected topics. Fourth, the processing of data and facts which are then linked to the determined theories to generate a particular concept or solution. Fifth, the writing process to complete the work as a scientific paper.

\section{RESULT AND DISCUSSION}

Based on literature and theoretical review, several solutions or concepts are determined to implement the financial literacy education in Accounting Education UMS. Among other is the partnership program with bank, which is aimed to reduce student consumptive behavior.

\section{Financial Literacy Education with SiMOLEK}

Financial literacy education is provided in a van called SiMOLEK - which stand from Mobil Literasi Keuangan. It is instigated by OJK and aimed to socialize and promote the financial literacy in remote areas. Initially, SiMOLEK only reaches 14 cities, namely Balikpapan, Bandung, Bogor, Cirebon, Denpasar, Jakarta, Makassar, Malang, Manado, Medan, Pekanbaru, Semarang, Solo, and Surabaya. It is equipped with multimedia and its complete features. It also provides educational materials, such as leaflets and brochures. 
Administrators are assigned in every unit to respond the questions about financial services products. By 2014, there are 20 units of SiMOLEK. To monitor its performance and progress, OJK conducts survey once in three years. Furthermore, OJK has released the National Strategy of Financial Literacy, in which there are 100 programs to be implemented within five years (2014-2019) in the blueprint of the strategy. Currently, OJK has not set the level of public financial literacy by 2019. The agency will start conducting the survey in 2016 to monitor the development of financial literacy in Indonesia.

The partnership program with OJK by bringing SiMOLEK is expected to raise the students' enthusiasm to explore the understanding of financial literacy. Education about financial literacy done in the classroom will be enriched by the presence of SiMOLEK along with the officer who will provide assistance related to questions about banking product service.

Importantly, as a banking product, the function of SiMOLEK should be recognized by the students and eventually, they will have better understanding on the benefits of financial management by using banking services. Similar to the common practice of saving in the bank, students will be habituated and trained to increase saving rather than consumption. It is an attempt to reduce consumptive behavior among students by start practicing their own finances since adolescence.

\section{Simulation of Banking Product}

In line with the establishment of SiMOLEK, the simulation of banking products is a product of partnership program. Accounting Education Study Program on behalf of Accounting Education students submits written application to the bank or OJK to conduct simulation of banking products within and outside the classroom. Furthermore, students are not charged since the financial literacy educational program is intended for the public, particularly the students, is a special program initiated by OJK and banking sector.

Simulation method is an alternative of learning for Accounting Education students to assist them in gaining learning experience and understanding toward the importance of applying financial literacy in daily life.

\section{Verbal and Written Socialization}

The verbal and written socialization has been a banking program to increase the public understanding on the importance of financial literacy. Verbal socialization can be applied in the financial literacy education, particularly for the students of Accounting Education UMS. It is conducted by submitting application to the bank and/or OJK to perform socialization to the campus during the class and regular seminar on finance organized by the Association of Accounting Education Students. In addition, general stadium that is usually held for new freshmen can be a medium to introduce the topic. 


\section{Preparation of Curriculum Design about Financial Literacy}

Financial literacy education incorporated in the curriculum of higher Education is begun with the preparation of curriculum design that contains material about financial literacy. It can be designed as a specific course or included in Financial Management course. The process of curriculum design in Higher Education must be based on the study and discussion that has been held between the lecturers, the Head of Study Program (Kaprodi) and the Vice Dean of academic affairs.

After the review and discussion process, curriculum in Higher Education particularly in Accounting Education Study Program which includes financial literacy is devised. It is done with the aim of improving the understanding of adolescents (students) in the application of financial literacy and to reduce student consumptive behavior.

- The provision of technical assistance in educational institutions

Technical assistance in relation with the practice of financial literacy is provided by banks and also OJK. Firstly, application should be submitted by educational institutions, particularly Higher Education. The practice of financial literacy includes the practice of saving, hence technical assistance that is expected to facilitate the practice of saving from the OJK or banks is the entire documents required to implement the practice of saving as well as the processing of savings transactions at the bank.

- Thematic Community Service Program on Financial Literacy

Thematic Community Service Program (KKN tematik) on financial literacy that can be done by students in Higher Education, particularly the students of Accounting Education who attend the financial literacy course. Through this program, students are expected to disseminate their knowledge to the public by conducting various socialization, training, and financial education during the program.

- The Presence of OJK outlet in UMS campus

Since 2015, OJK has initiated partnership with several universities. The program includes the presence of OJK outlet on campuses as a means of conveying information and education about the characteristics, services, and products of Financial Services Institution, and providing access to public complaints. In 2015, OJK listed universities that had conducted partnership with OJK comprising of Perbanas Institute, Universitas Indonesia, Universitas Gadjah Mada, Universitas Diponegoro, Universitas Muhammadiyah Malang, Universitas Wakhid Hasyim, Universitas Teknologi Sumbawa, Universitas Muhammadiyah Prof. Dr. Hamka, Indonesia Banking School, Sekolah Tinggi Ilmu Ekonomi Bisnis Indonesia (STIEBI), and Sekolah Tinggi Manajemen IMMI (STIMA IMMI). The OJK outlet can also be established in UMS campus by applying such a partnership with OJK to be facilitated and supplied by OJK in setting up a MoU. 


\section{CONCLUSION}

The discussion about the financial literacy has been done in which it is concluded that the students' consumer behavior can be reduced by providing financial literacy education in Higher Education. The programs that can be implemented in Higher Education are: a) SiMOLEK or financial literacy van to provide financial literacy education to students; b) Simulation of banking products; c) Verbal and written socialization; d) Inclusion of financial literacy in the educational curriculum design; e) Provision of technical assistance in facilitating educational institutions; f) Thematic Community Service Program $(K K N)$ on financial literacy; and g) Provision of the OJK outlet on campus. 


\section{REFERENCES}

Bere, S. M. (2016). Rendah, tingkat pemahaman masyarakat terhadap produk keuangan. Retrieved from http://bisniskeuangan.kompas.com/read/2016/03/29/074500526/Rendah.Tinkat.Pema haman.Masyarakat.terhadap.Produk.Keuangan at Nopember 14, 2017.

Chen, H., \& Volpe, R. P. (2002). "Gender Differences in Personal Literacy Among College Students". Financial Services Review, 11, p. 289-307.

Creswell, J. W. (2009). Research Design: Qualitative, Quantitative, And Mixed Methods Approaches. Newbury Park: Sage Publications.

Lusardi, Anamaria, et., al. (2010). "Financial Literacy Among the Young". Journal of Consumer Affairs, 44(2), p. 358-380.

Lusardi, A., \& Mitchell, O. S. (2014). "The Economic Importance of Financial Literacy: Theory and Evidence". Journal of Economic Literature, 52, p. 5-44.

Otoritas Jasa Keuangan (OJK). (2015). Program pengembangan sektor jasa keuangan dan peningkatan literasi keuangan serta perlindungan konsumen. Retrieved from http://www.ojk.go.id/Files/201510/SiaranPersMoUOJK UNPAD _1443709490.pdf, at November 15, 2017.

Sebayang, S., Yusuf, M., \& Priyatama, A. N. (2011). Hubungan Antara Body Image Dan Konformitas dengan Perilaku Konsumtif Pada Siswi Kelas XI SMA Negeri 7 Surakarta. Jurnal Psikologi, 3(6), p. 5-41.

Setiawan, S. R. D. (2017). Perluas Literasi Keuangan, OJK Jalin Kerja Sama dengan Muhammadiyah. Retrieved from http://ekonomi.kompas.com/read/2017/04/ 18/180520926/perluas.literasi.keuangan.ojk.jalin.kerja.sama.dengan.muhammadiyah, at November 14, 2017.

Rombe. (2014). Hubungan Body Image Dan Kepercayaan Diri Dengan Perilaku Konsumtif Pada Remaja Putri Di SMA Negeri 5 Samarinda. Samarinda: Program Studi Psikologi, Fakultas Ilmu Sosial Dan Ilmu Politik, Universitas Mulawarman.

Stabilitas. (2014). Literasi Keuangan Itu Investasi Jangka Panjang. Retrieved from http://stabilitas.co.id/home/detail/literasi-keuangan-itu-investasi-jangka-panjang, at November 15, 2017.

Tomaskova, Hana, et.al. (2011). Issues of Financial Literacy Education. Procedia - Social and Behavioral Sciences, 28, p. 365-369. 